\title{
Does Monetary Policy matter for Agricultural Sector Performance? Empirical Evidence from Nigeria
}

\author{
Victor Ugbem Oboh* Moses Kpughur Tule and Godday Uwawunkonye Ebuh \\ Monetary Policy Department, Central Bank of Nigeria
}

\begin{abstract}
The paper examined the impact of monetary policy on agricultural sector performance in Nigeria, using annual data spanning the period 1981 to 2016. Given its significant role in providing employment to about $60 \%$ of the economically active population and $70 \%$ of the country's poorest communities, agriculture has huge potential for achieving poverty reduction in Nigeria. In this regard, the study employed the Autoregressive-Distributed Lag (ARDL) approach and established a long- run relationship between agriculture value added and some monetary policy variables. Specifically, the findings suggested that in the long-run, money supply and maximum lending rate have significant effects on agriculture value added while exchange rate and inflation do not. Given the important role of money supply in promoting agricultural sector performance, the paper recommends an expansionary but non-inflationary monetary policy to improve value addition to the agricultural sector of the Nigerian economy.
\end{abstract}

Keywords: Agricultural Value Added, Monetary Policy, ARDL approach, Nigeria.

DOI: $10.7176 / \mathrm{JESD} / 10-12-05$

Publication date:June $30^{\text {th }} 2019$

\section{Introduction}

It is well known that agriculture constitutes the economic mainstay of majority of Nigerian households and contributes significantly to the overall economy (Oni etal, 2009). Agriculture provides food, raw materials, foreign exchange and contributes substantially to the gross domestic product (GDP). The sector has huge potential for achieving poverty reduction in Nigeria, given its significant role in providing employment to about $60 \%$ of the economically active population and $70 \%$ of the country's poorest communities (Oboh and Adeleke, 2016). Since majority of the poor population in developing countries such as Nigeria reside in rural areas and engage in agriculture as their main source of livelihoods; any effective poverty reduction and sustainable growth strategy must necessarily involve agriculture (Todaro and Stephen, 2004).

Agricultural sector development depends largely on the impact of macroeconomic policies in form of fiscal, monetary and trade variables (Aroriode and Ogunbadejo, 2014). Macroeconomic policies are generally designed with positive intentions; however, some of the policies may often have unintended and harmful outcomes especially on agriculture. A sound macroeconomic framework that is conducive to growth is usually characterized by low and stable inflation; investment-friendly real interest rate; a competitive and stable real exchange rate, a sustainable fiscal policy and a viable balance of payment (Fischer, 1993). This implies that accelerated agricultural growth largely depend on a sound and effective macroeconomic policy environment.

The agricultural sector in Nigeria has attracted considerable government policy attention overtime due to its crucial role in economic development. In particular, the strong linkages (both forward and backward) between agriculture and other sectors of the economy has necessitates a robust understanding of the influence of monetary policy outcomes on agriculture.

As the farm sector becomes increasingly integrated with the nonfarm sector; macroeconomic developments both at the domestic and international levels tends to significantly affect costs of farm inputs, product prices, farm income and profitability levels. This is particularly true with respect to monetary variables such as exchange rates, interest rates, and inflation as well as their impacts on the farm sector (Devadoss, 1985).

The role of monetary policy in promoting economic growth dates back to the time of Adam Smith and notable monetary economists such as Fishers, Tobin and Friedman. Since then, there has been a growing consensus among monetary economists and policy practitioners that monetary policy matters significantly for growth at least in the short-run. However, the focus of monetary policy researchers has recently shifted from whether or not money matters, to investigating the role of monetary policy in real sector growth. Among several aspects that have received considerable policy attention is the impact of monetary policy shocks on various economic sectors. Evidence has shown varying responses of different economic sectors to monetary shocks (Ibrahim, 2005; Hayo and Uhlenbrock, 1999).

This development portends significant policy implications for macroeconomic management as monetary authorities would necessarily have to weigh the consequences of its policies on different sectors of the economy. For a developing country like Nigeria in particular where agriculture remains a critical sector of the economy; such an impact study would provide valuable insights to the effectiveness of monetary policy in promoting agricultural growth. 
Changes in monetary policy variables such as interest rate, exchange rate or inflation might significantly impact the prices and incomes of the agricultural economy. One of such is the fluctuation in the value of the local currency relative to other currencies which has considerable implications for agricultural trade. For example, an expansionary monetary policy stance is likely to reduce the value of the local currency which may in turn, stimulate exports and increase aggregate demand for agricultural commodities. Similarly, increase in inflation is likely to heighten prices of both farm inputs and outputs, and, therefore affect investment decisions. Also, changes in monetary policy stance affect the interest rate which in turn influences farmers' decision to borrow credit.

Monetary authorities such as the central banks implement monetary policy decisions using various instruments such as monetary policy rate, cash reserve ratio, open market operations and liquidity ratio. In particular, adjustment in the policy rate determines the rate that banks charge each other for short-term loans. These changes are reflected in other short-term interest rates which ultimately affect borrowing costs for firms and households (Benazic and Rami, 2016). For example, a fall in policy rate will lead to a corresponding reduction in bank lending rate. This will translate to cheap borrowing cost and in turn encourage agricultural households and firms to increase production.

The money market provides a trading intermediary where funds from surplus units are deployed to deficit units. Since agricultural investments such as farming require funding; farmers, agro-processors and other agricultural sector stakeholders participate actively in the money market (Muroyiwa et al, 2014).

Agricultural sector practitioners such as farmers borrow funds from the money market to purchase farm inputs including machinery, seeds, fertilizers, land and chemicals as well as working capital. Agricultural sector performance depends considerably on availability of credit which, in turn, is a function of interest rate; hence the linkage between monetary policy and agriculture. This paper will specifically investigate the effects of monetary policy on agriculture value added. Given the significant contribution of agriculture to Nigeria's economy, the study would deepen our understanding of the impact of monetary policy on the agricultural sector and provide a guide on how to develop more effective policies towards increasing value addition and enhance international

\section{Literature Review}

\subsection{Theoretical Literature}

Most economies across the globe pursue sustainable economic growth, low unemployment and external balance as their core objectives. Discussions on growth theory have, over time, been dominated by both the classical and the neo-classical schools of thought. The classical theory, on the one hand, is based on the viewpoint that in a capitalist setting, all markets are cleared and prices are flexible enough to attain equilibrium automatically. The Solow-Swan Neoclassical growth model, on the other hand, attributed long-run growth to two exogenous variables which include technical progress and growth in labour and capital (Olarinde and Abdullahi, 2014). That is, an equilibrium state can be attained by varying the quantities of capital and labour in the production process. It also emphasized the critical role of technological change on economic growth.

However, the model did not establish any clear link between macroeconomic policies and labour force growth, thus, suggesting limited influence of government policies (Jinghan, 2010). The observed deficiencies noticed in the Solow-Swan Neoclassical growth model prompted the development of the Endogenous Growth Theory pioneered by Romer (1986) and Lucas (1988). According to this theory, technological change can be endogenously influenced and that changes in both human and non-human capital could result in positive externalities. However, the model failed to clearly assign any role to macroeconomic policies in determining growth.

In contrast to the above-mentioned theories, the experiences of the 1970s and 1980s provided sufficient evidence to suggest that sound macroeconomic policies are necessary to achieve long-term sustainable economic growth. For instance, the impressive growth performance of the four Asian Tigers as well as South East Asian economies were largely attributed to changes in macroeconomic policies that promoted low inflation and favourable fiscal policies. Similarly, the awful performance of some Latin American and African economies in the 1980s popularly referred to as the 'lost decade' could be traced not only to unstable political environment but also to weak macroeconomic policies (Lachaal, 1994).

Government influences economic activities in line with its set objectives through macroeconomic policy instruments which are either fiscal or monetary. In the case of fiscal policy, government uses expenditure, taxes and subsidies to achieve certain macroeconomic objectives. However, this study focuses on the effects of monetary policy on agricultural sector growth in Nigeria.

Monetary policy may either be expansionary or contractionary. It is expansionary if the objective is to increase money supply by reducing the interest rate; while for contractionary monetary policy, the reverse holds. The classical view of monetary policy asserts that money plays a neutral role in the economy and change in money supply has no significant effect on real variables such as output, income and employment. The Keynesian theorists however opined that prices are sticky and markets are unable to clear on their own without external intervention. This implies that an economy can continue to remain in a state of low output and high unemployment unless 
government intervenes. For instance, the traditional Keynesians in line with the IS-LM monetary policy transmission model posits that an expansionary monetary policy stance which increases money supply and reduces interest rate would stimulate investment and output (Cioran and Cuza, 2014).

According to the monetarist school of thought, led by Milton Friedman in 1968, money plays a critical role in all economic activities and as such, monetary policy tends to be more effective in the implementation of economic stabilization programmes than fiscal policy. In their opinion, money is the most critical regulatory instrument in an economy and monetary authorities should concentrate on ensuring price stability to avoid an inflationary economy which is harmful to growth.

The Keynesian monetary transmission mechanism posits that, for an economy at less than full employment equilibrium; monetary policy impulses transmit through the financial system via the interest rate channel to the real sector. According to Keynes, given the indirect relationship between the quantity of money and prices; any increase in money supply will lead to a fall in interest rate which will stimulate investments. An increase in the volume of investments will in turn stimulate effective demand, increase output, income and employment (Gbosi, 2005).

\subsection{Empirical Literature}

Understanding the macroeconomic linkages between monetary policy and various measures of agricultural performance has stimulated considerable empirical research interest globally, and especially in the United States. Some of the early contributions to this area of research include Schuh, (1974); Shei, (1978); Barnett et al, (1981); Chambers, (1984); Odin, (1986); Odin and Fackler, (1989). Most of these research works investigated the relationship between monetary policy and aggregate farm sector variables as well as the impact of key macroeconomic variables on agricultural outcomes. Their findings indicated significant linkage between monetary policy and farm sector performance, on the one hand, and macroeconomic variables and agricultural sector performance, on the other hand. In addition, Babula et al (1995) employed cointegration technique to investigate the role of exchange rate on US corn exports. Their results, however, failed to establish any evidence of long run relationship among exchange rate, sales, price and corn exports.

There are some similar studies that empirically investigated the impact of macroeconomic factors, including monetary policy variables, on agricultural performance. For instance, Asfaha and Jooste (2007) examined the response of agricultural price to monetary policy in South Africa. By analysing monthly data with Johansen cointegration and Vector Error Correction model (VECM), the authors found a long run relationship between agricultural prices, on the one hand, and monetary policy and exchange rate, on the other hand.

Muroyiwa et al (2014) studied the linkages between some macroeconomic variables and agricultural sector outcomes. Using VECM, with data spanning 1970 and 2011, the findings amongst others, indicated a significant but negative impact of inflationary shocks and money market rates on agricultural GDP performance. The study also showed that a unit increase in money market rate reduces agricultural GDP by about 0.021 percentage points. Also, Kiptui (2007) used the Autoregressive Distributed Lag (ARDL) model to examine the impact of real exchange rate (RER) on the demand for Kenya's exports. The result however showed a short-run positive, but insignificant impact of RER on Kenya's exports.

Some empirical research using the Nigerian data have also been undertaken to assess the relationship between monetary policy variables and agricultural performance. Onyilola (2008) investigated the impact of exchange rate and tariff rate changes on import prices in Nigeria. The study employed ECM to show that in the short run, exchange rate exhibited positive and significant pass-through to import prices of consumer goods.

Another study by Abiodun and Sheu (2010) examined the response of agricultural output to changes in prices and exchange rate in Nigeria. By applying cointegration and vector error correction method, the authors established in the long run, that about $57 \%$ changes in agricultural output could be jointly explained by changes in RER, food and export prices. In addition, the study observed an immediate pass-through effect of exchange rate and food prices to agricultural output.

Sunday et al (2012) also investigated the impact of exchange rate and other variables on agricultural productivity using cointegration and ECM. The study showed a positive impact of nominal exchange rate and capacity utilization on agricultural productivity, both in the long and short run. In a similar vein, Oriavwote and Oyovwi (2014) employed cointegration and ECM to estimate the impact of REER on agricultural productivity in Nigeria. The results indicated a positive and significant impact of REER and export price on agricultural productivity.

Another related study by Makinde (2012) evaluated the effect of money supply and other macroeconomic factors on prices of agricultural commodities in Nigeria. Using least squares estimation method, the results show a significant impact of money supply on agricultural prices. In addition, about $86.2 \%$ of variation in agricultural prices was attributed to changes in money supply and exchange rate showing the substantial contribution of monetary policy variables to changes in agricultural prices.

The effectiveness of monetary policy in promoting agricultural development in Nigeria was the focus of 
another study by Ehinomen and Akorah (2012). The authors employed the ordinary least squares method with data covering 1970 and 2010 to show the positively significant impact of money supply on agricultural output. However, the minimum rediscount rate and treasury bill rate were found to be insignificant. The general conclusion from most of the reviewed empirical studies suggest that monetary policy variables especially REER and money supply, matters considerably, for agricultural performance.

\section{Data and Methodology}

\subsection{Data and Measurements}

The primary objective of this paper was to determine the impact of monetary policy on agricultural sector performance in Nigeria by employing the Autoregressive Distributed Lag (Bounds Testing). Annual data for five selected variables covering 1981 to 2016 were used for the analysis. These variables include agriculture value added, real exchange rate, money supply, inflation and maximum lending rate. All the datasets were sourced from the Central bank of Nigeria website, except for the agriculture value added, that was obtained from the World Bank website.

For this study, we adopt agriculture value added as a measure of the performance of agricultural sector. Agriculture value added ${ }^{1}$ refers to the net output from agricultural sector, inclusive of forestry, hunting and fishing, as well as crops and livestock production, after adding up all outputs and subtracting intermediate inputs (World Bank, 2018). Some other measures of agricultural sector performance include contribution of agriculture to national GDP, agricultural productivity and agricultural growth rate. Our choice of agriculture value added is based on the current structure of Nigeria's economy whose exports is predominantly composed of primary commodities. Rapid industrialization through value added development with backward and forward linkages has been recognized as a viable economic diversification strategy.

\subsection{Model Specification}

We estimated the agriculture value added equation by employing the ARDL modelling methodology (Pesaran et al, 2001). The choice of this approach is due to its flexibility of application irrespective of whether the regressors are $\mathrm{I}(0)$ or $\mathrm{I}(1)$. The second advantage relates to its flexibility for each variable to have a different lag length as symmetry of lag length is not necessary.

Two steps are involved in performing the ARDL analysis. First, we conduct the bounds test to ascertain the existence of cointegration among the variables. If cointegration exists, following the results of bounds test, the second step would then proceed to estimate the long term relationship and the associated error correction model. The ARDL model is specified below:

$$
\begin{aligned}
\Delta \text { LAGVAL }_{t}=a_{0} & +\sum_{t=1}^{p} a_{1} \Delta \text { LAGVAL }_{t-1}+\sum_{t=1}^{p} a_{2} \Delta \mathrm{LM}_{t-1}+\sum_{t=1}^{p} a_{3} \Delta \mathrm{INF}_{t-1}+\sum_{t=1}^{p} a_{4} \Delta \mathrm{MLR}_{t-1} \\
& +\sum_{t=1}^{p} a_{5} \Delta \mathrm{LREER}_{t-1}+\sum_{t=1}^{p} \gamma_{1} \Delta \mathrm{LAGVAL}_{t-1}+\sum_{t=1}^{p} \gamma_{2} \Delta \mathrm{LM}_{t-1}+\sum_{t=1}^{p} \gamma_{3} \Delta \mathrm{INF}_{t-1} \\
& +\sum_{t=1}^{p} \gamma_{4} \Delta \mathrm{LM}_{t-1}+\sum_{t=1}^{p} \gamma_{5} \Delta \text { LREER }_{t-1}+\epsilon_{t}
\end{aligned}
$$

Where:

AGVAL = Agricultural value added;

M2 = Money supply;

$\mathrm{INF}=$ Inflation rate;

MLR = Maximum lending rate and

REER $=$ Real effective exchange rate.

The expressions $\gamma_{1}, \gamma_{2}, \gamma_{3}, \gamma_{4}$ and $\gamma_{5}$ are the long-run multipliers while $a_{1}, a_{2}, a_{3}, a_{4}$ and $a_{5}$ represent shortrun dynamic coefficients. The term $a_{0}$ represents the intercept; $\mathrm{t}$ is the deterministic trend line while $\epsilon_{t}$ is assumed to have no serially uncorrelated residuals with zero mean. It is important to note the exclusion of the current values of $\triangle \mathrm{LM}, \triangle \mathrm{INF}, \triangle \mathrm{MLR}$ and $\triangle \mathrm{REER}$ as it is impossible to have a priori information about the long-run status of the determinants of agricultural value added.

The next step involves the testing of the existence of a long-run relationship among variables using the F-test. The joint hypothesis that the lagged values of the variables in equation 1 are zero is stated as:

$H_{0}=\gamma_{1}=\gamma_{2}=\gamma_{3}=\gamma_{4}=\gamma_{5}=0$

\footnotetext{
${ }^{1}$ In calculating agriculture value added, no deductions are made for depreciation of fabricated assets or depletion and degradation of natural resources.
} 
Conversely, the alternative hypothesis is given as:

$H_{1}=\gamma_{1} \# 0 ; \gamma_{2} \# 0 ; \gamma_{3} \# 0 ; \gamma_{4} \# 0 ; \gamma_{5} \# 0$

We then compare the computed F-statistics with the critical values. There are two sets of asymptotic critical values. While one set is based on the assumption that all variables in the model are I(1); the other set assumes that the variables are $\mathrm{I}(0)$.

The null hypothesis of long-run relationship can be rejected without minding the order of integration of the variables, if the value of the computed F-statistics is higher than the upper band. Conversely, the null hypothesis of no long-run relationship can be accepted on the condition that the value of the computed F-statistics is smaller than the lower band. However, the result can be declared inconclusive, if the value of the computed F-statistic falls between the two bands.

\section{Empirical Results}

As a prelude to further analysis, Figures 1-5 show the movements of the variables in the model.

\section{Agriculture Value Added (Nbillion)}
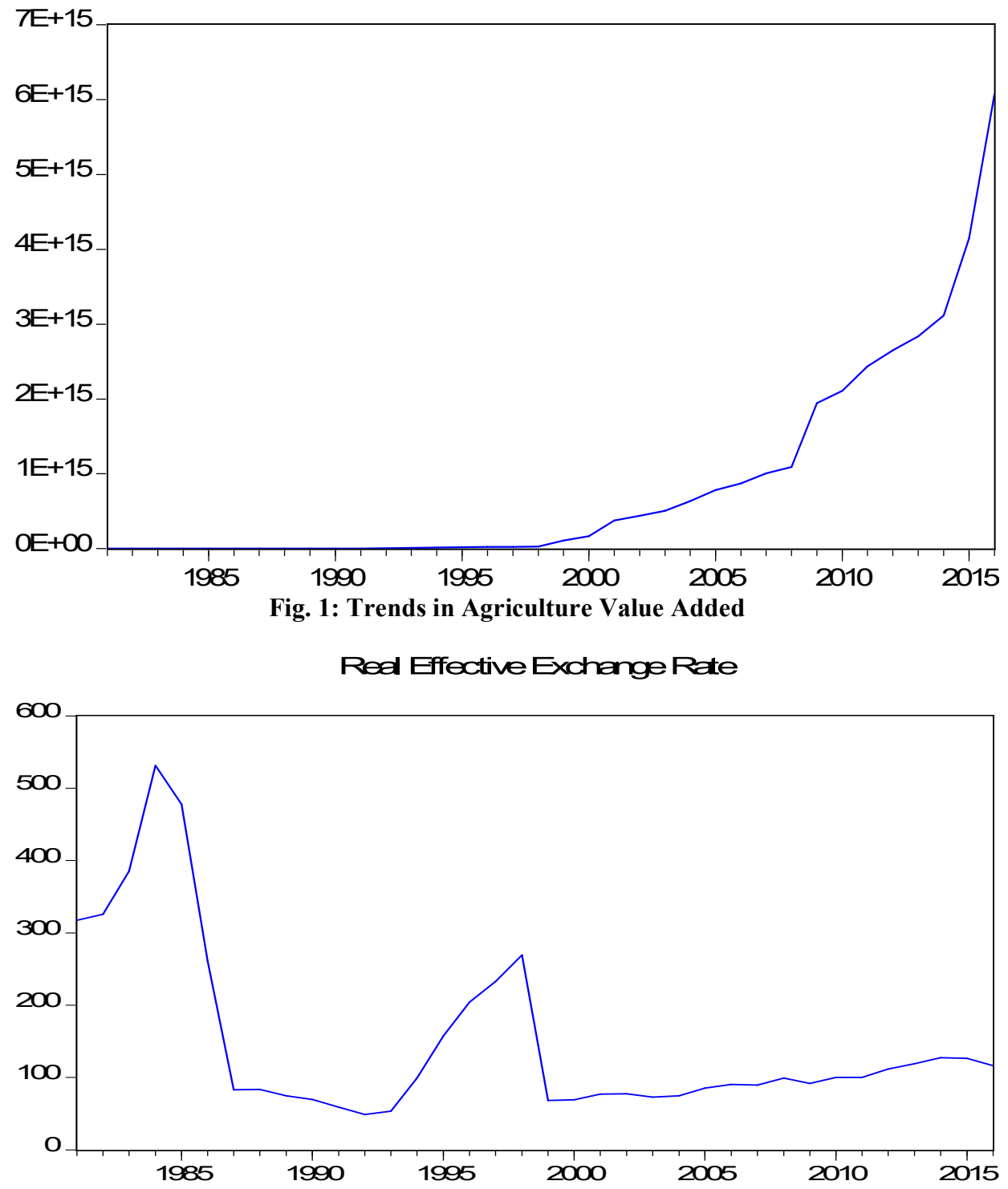

Fig. 2: Trends in Real Effective Exchange Rate 


\section{Inflation}

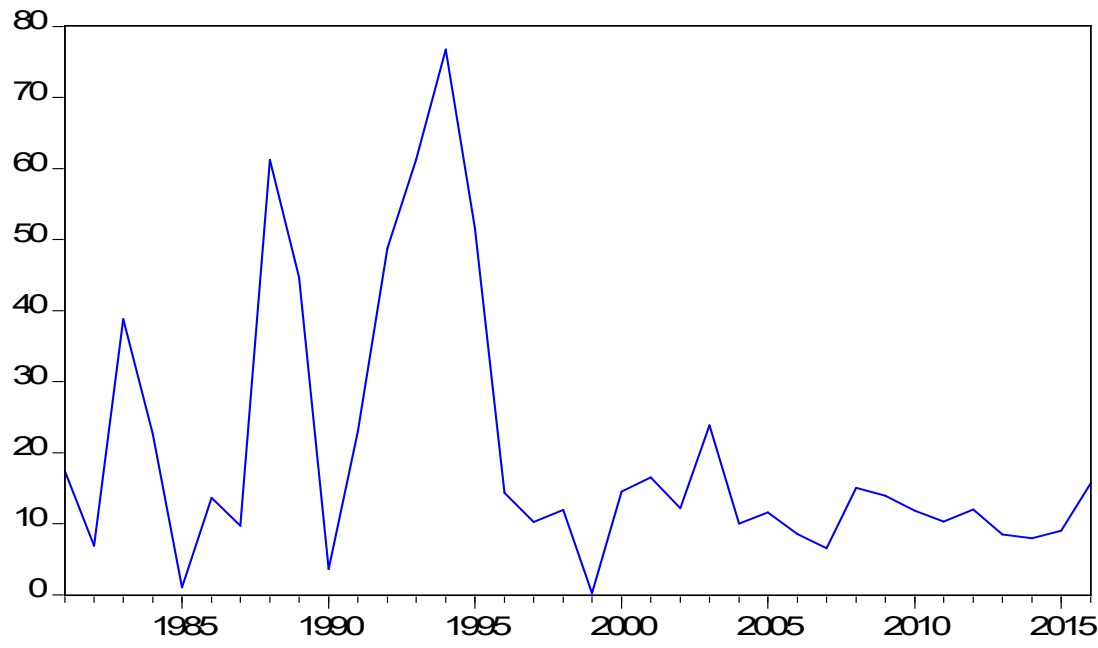

Fig. 3: Trends in Inflation

Money Supply (MR)

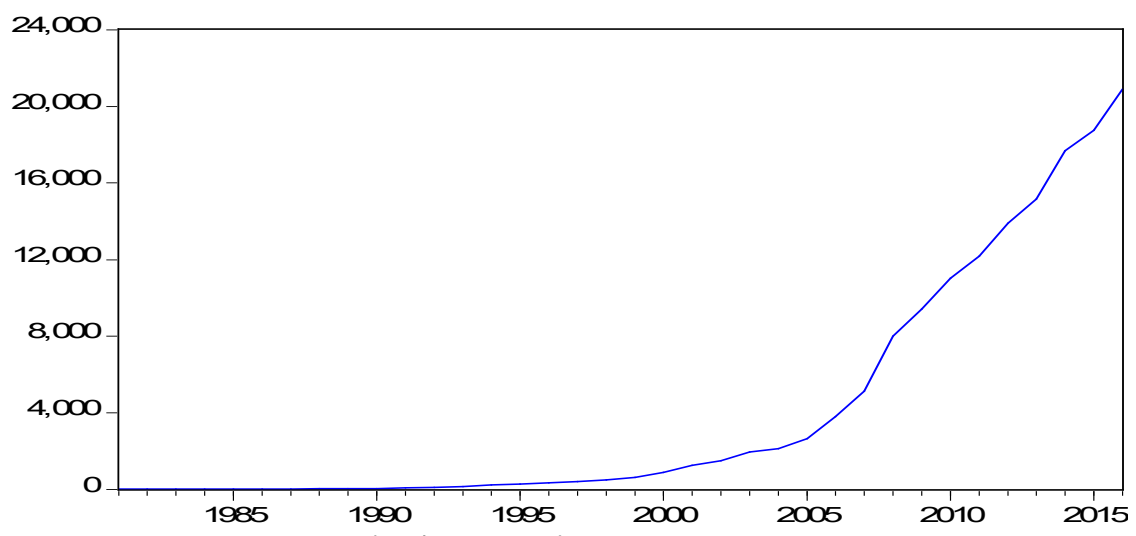

Fig. 4: Trends in Money supply

MeximumLending Rate

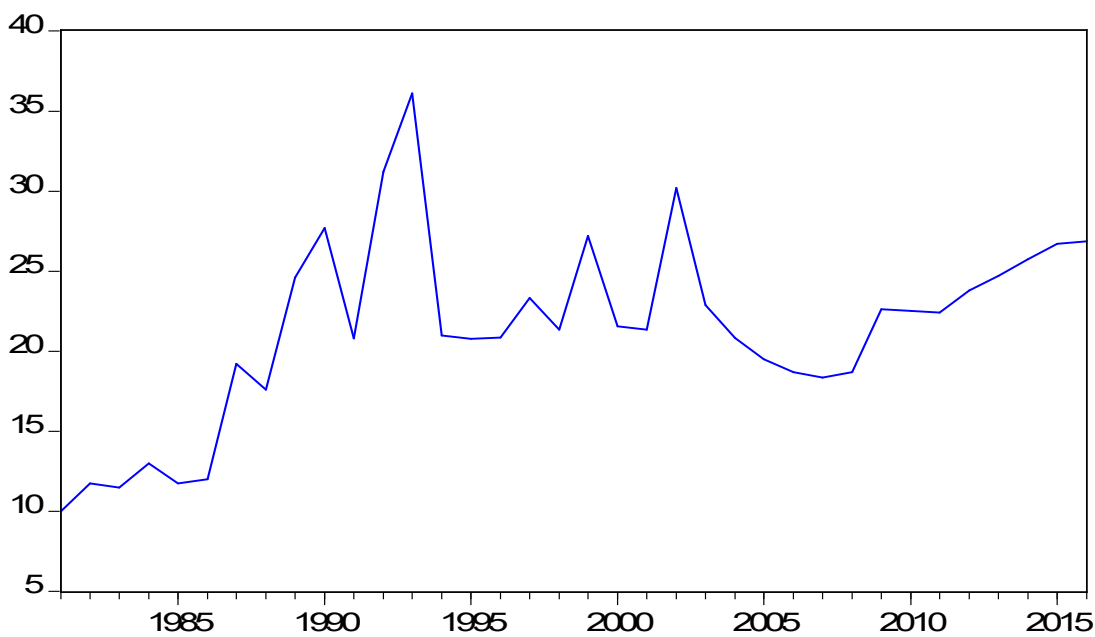

Fig. 5: Trends in Maximum Lending Rate

Both agriculture value added and money supply (M2) showed very similar upward movements beginning from the mid-1990s till 2016. However, a slowdown in the upward trend was observed around 2008, corresponding 
to the period of the global financial crisis. The progress recorded in the agriculture sector also coincided with Nigeria's return to democratic rule in 1999. Under the administration of President Obasanjo (1999-2007), key economic and agricultural policy reforms were implemented. Some of these include the National Economic Empowerment and Development Strategy (NEEDS), the National Agricultural Policy (2002) and the National Special Programme on Food Security (NSPFS) (2002). During this period, the role of government was clearly redefined to creating the conducive macro-environment to stimulate greater private sector investment in agriculture rather than direct participation. In this regard, the private sector appropriately assumed its role as the lead actor in agricultural business. The Agricultural Transformation Agenda of Goodluck Jonathan's administration with special focus on enhancing farmers' access to key inputs also contributed to the progress made in agricultural development.

The real effective exchange rate showed several breaks. The most significant depreciation occurred in 1986 following the introduction of the Structural Adjustment Programme (SAP) and the consequent adoption of the flexible exchange rate regime by the CBN (Adeoye and Atanda, 2012). As a result, the exchange rate recorded a 55.9 per cent depreciation from N0.89 in 1985 to N2.02 in 1986 and to N7.65/US\$ by the end of 1990. The increased demand for the dollar led to a further depreciation to N22.69/US\$ in 1993 under the foreign exchange market (FEM) before gaining relative stability at an average of N21.88/US\$ between 1994 and 1998 (Danmola, 2013). Since then, real effective exchange rate has remained low largely due to the occurrence of the global economic and financial crisis that proceeded the fall in crude oil prices in 2008 and 2009. The intense pressure mounted by the sharp drop in the price of oil in 2014 which led to a significant fall in external reserves also triggered exchange rate crisis and largely plunged the economy into recession. The outcome was a huge depreciation in the exchange rate with the interbank rate, depreciating from N160/US\$1 in 2014Q2 to N186/US\$1 by October 2014, N216/US\$1 by January 2015 and N360/US\$1 by 2016.

It could be observed that the increase in agriculture value added is largely accompanied by the depreciation of the exchange rate, and vice versa. This is glaring during periods of economic crisis that resulted in reduced capital inflows leading to the depreciation of the exchange rate. Such periods between 2000 and 2016 include the fall in oil prices in the late 1990s, the impact of the global financial crisis of 2007-2009 and the crude oil price shock of 2014.

Before conducting the bounds test, we first examine stationarity properties of the time series in order to determine their order of integration. This is important to avoid the production of spurious results. For the bounds test, variables that are integrated of order $n=0,1$, are acceptable for further analysis while I(2) variables are invalid. In carrying out the stationarity test of the series, we employed the Augmented Dickey-Fuller (ADF) (Dickey \& Fuller, 1979), and Kwiatkowski-Phillips-Schmidt-Shin (KPSS) (1992) unit root tests. The results are presented in Tables 1 and 2. All the series except inflation are expressed in logarithms to ensure the stability of the variance. The ADF tests suggest that inflation was stationary at levels while the rest of the variables exhibited stationarity at first difference. However, the KPSS test indicated that only agriculture value added and maximum lending rate were stable at first difference while inflation, real effective exchange rate and money supply were stationary at levels. In both cases, it can be concluded that the series were integrated of order I(1) and I(0) and therefore satisfied the requirement for the use of ARDL (bounds test) approach for analysis.

Table 1. ADF unit root tests results for stationarity of the variables

Variable Level First Difference $\mathrm{I}(\mathrm{d})$

\begin{tabular}{|c|c|c|}
\hline LAGVAL & - & $-5.179 * \mathrm{I}(1)$ \\
\hline LM2 & - & $-2.667 * * \mathrm{I}(1)$ \\
\hline LMLR & - & $-6.062 * \mathrm{I}(1)$ \\
\hline INF & $-3.08 *$ & $\mathrm{I}(0)$ \\
\hline LREER & - & $-4.439 * \mathrm{I}(1)$ \\
\hline
\end{tabular}

Notes: * and ** indicate statistical significance at 1 per cent and 5 per cent levels respectively while I(d) denotes order of integration

Table 2. KPSS unit root tests results for stationarity of the variables in the equation

\begin{tabular}{llll}
\hline Variable Level & & First Difference & $\mathrm{I}(\mathrm{d})$ \\
\hline LAGVAL & - & $-0.119^{* *} \mathrm{I}(1)$ \\
LM2 & $0.100^{*}$ & - & $\mathrm{I}(0)$ \\
LMLR & - & $0.171^{*}$ & $\mathrm{I}(1)$ \\
INF & $0.317^{*}$ & - & $\mathrm{I}(0)$ \\
LREER & $0.257^{*}$ & - & $\mathrm{I}(0)$
\end{tabular}

Notes: * and $* *$ indicate statistical significance at 1 per cent and 5 per cent levels respectively while I(d) denotes order of integration

Thereafter, we conducted the F-statistics to determine the level of cointegration. Due to the sensitivity of the ARDL 
procedures to the lag length, we carefully selected the lag length by using the SIC method as recommended by Peseran et al (2001.) In this regard, the ARDL model $(1,1,3,4,3)$ is selected to investigate the long run relationship among the variables. The variables are ordered as agriculture value added, inflation, money supply, maximum lending rate and real and effective exchange rate.

Table 3 showed the F-statistics cointegration test as well as the critical values. The results indicate that the computed F-statistic $($ F-statistic $=22.75)$ exceeds the upper bound critical value of 4.01 at the 5 per cent level of significance. Given this result, we cannot accept the null hypothesis of no cointegration at the 5 per cent level of significance. Therefore, the result shows that cointegrating relationship exists among the variables.

Table 3. F-Statistic showing the cointegrating relationship

Bounds Critical Values

\begin{tabular}{lccccl} 
Test & \multicolumn{5}{l}{ Significance } \\
Statistic & Value & Lag & level & $\mathrm{I}(0)$ & $\mathrm{I}(1)$ \\
\hline F-Statistic & 22.75 & 2 & & & \\
& & & $1 \%$ & 3.74 & 5.06 \\
& & $5 \%$ & 2.86 & $4.01^{* *}$ \\
& & & $10 \%$ & 2.45 & 3.52 \\
\hline
\end{tabular}

** denotes significance at 5 per cent level

Next, we estimated the long-run and short-run coefficients based on the ARDL co-integrating method and the results are as shown in Tables 4 and 5. Results indicate that in the long-run, money supply and maximum lending rate have significant effects on agriculture value added. Money supply had an expected positive sign with a coefficient of 1.29 and statistically significant at 1 per cent. This implies that a $1 \%$ increase in money supply will increase agriculture value added by 1.29 per cent. The positive impact of money supply on agricultural value added agrees with economic theory. That is, an increase in nominal money supply causes a decrease in nominal interest rate which encourages borrowing for investment purposes, hence, a boost in agriculture value added (Thapa, 2002). The results tend to re-affirm the relevance of expansionary monetary policy stance in promoting agricultural development. It however disagreed with an earlier study by Aroriode and Ogunbadejo (2014) that found an inverse relationship between money supply and agricultural output. The contrasting findings may be due to the different measures of agricultural sector performance adopted by the two studies.

Inflation rate showed an insignificant relationship with agriculture value added, but it exhibited a negative sign in line with a priori expectation. This implies that price instability affects agriculture negatively. According to economic theory, inflation discourages investment especially in the real sector as it causes a decline in the real return on investment. One of the major channels through which inflation affects agricultural investment is the increase in the price of agricultural inputs which reduces profitability.

Real effective exchange rate showed a negative and insignificant impact on agriculture value added. The sign of the coefficient is contrary to a priori expectation. The statistical insignificance of REER coefficient suggests that exchange rate channel is not important in boosting agricultural development in Nigeria. The findings reflect the largely primitive nature of Nigerian agriculture characterized by low level of sophisticated and imported inputs and exported outputs (Onwuka, 2017). It could also imply that international competitiveness of the Nigerian economy does not significantly affect agricultural performance. However, in sharp contrast to this result, Oriavwote and Oyovwi (2014 found REER to have significant impact on agricultural output in Nigeria. Again, the contrasting finding could be attributed to the different dependent variables used by the two studies.

Table 4. Long-run estimates of ARDL

\begin{tabular}{lllll}
\hline \multicolumn{2}{l}{ Dependent variable: Log of Agriculture Value Added } & \\
\hline Regressors & Coefficient & SE & T-statistics & Prob. \\
\hline INF & -0.000027 & 0.005784 & -0.004615 & 0.9964 \\
LM2 & $1.290656^{*}$ & 0.043870 & 29.419863 & 0.0000 \\
LMLR & $4.102283^{*}$ & 0.501223 & 8.184553 & 0.0000 \\
LREER & -0.105502 & 0.229403 & -0.459899 & 0.6522
\end{tabular}

\footnotetext{
*denotes significance at 1 per cent.

Results of the short-run estimates are shown in Table 5. All the variables in consideration except LM2, were significant at 5 per cent suggesting that agriculture value added is impacted strongly by inflation, lagged money supply, lending rate and exchange rate in the short-run. Also, the signs of all the variables, except inflation conformed to a priori expectation.
} 
Table 5. Short-run estimates of ARDL

Dependent variable: $\Delta$ Agriculture Value Added

\begin{tabular}{lllll}
\hline Regressors & Coefficient & SE & T-stat. & Prob. \\
\hline$\Delta$ INF & 0.003046 & 0.001175 & 2.592002 & 0.0204 \\
$\Delta$ LM2 & -0.365380 & 0.190440 & -1.918611 & 0.0743 \\
$\Delta$ LM2(-1) & 0.914060 & 0.186127 & 4.910950 & 0.0002 \\
$\Delta$ LM2(-2) & 0.743987 & 0.177641 & 4.188145 & 0.0008 \\
$\Delta$ LMLR & -0.326223 & 0.108618 & -3.003388 & 0.0089 \\
$\Delta$ LMLR(-1) & -1.626572 & 0.147029 & -11.062947 & 0.0000 \\
$\Delta$ LMLR(-2) & -1.005725 & 0.141418 & -7.111736 & 0.0000 \\
$\Delta$ LMLR(-3) & -0.434716 & 0.100897 & -4.308506 & 0.0006 \\
$\Delta$ LREER & -0.965700 & 0.053338 & -18.105249 & 0.0000 \\
$\Delta$ LREER(-1) & -0.245225 & 0.061860 & -3.964199 & 0.0012 \\
$\Delta$ LREER(-2) & -0.410079 & 0.053276 & -7.697281 & 0.0000 \\
C & 3.485811 & 0.289556 & 12.038471 & 0.0000 \\
ECM & -0.308902 & 0.025732 & -12.004711 & 0.0000
\end{tabular}

Diagnostic tests:

Adjusted R-squared $=0.96$

F-stat $=3788.55($ Prob $=0.00) ; \mathrm{DW}=2.48$

Serial correlation: $\mathrm{X} 2=4.68(\mathrm{Prob}=0.40)$

Linearity $=2.101($ Prob $=0.58)$

Heteroscedasticity: X2=1.89 (Prob=0.13)

CUSUM=Stable; CUSUMSQ=Stable

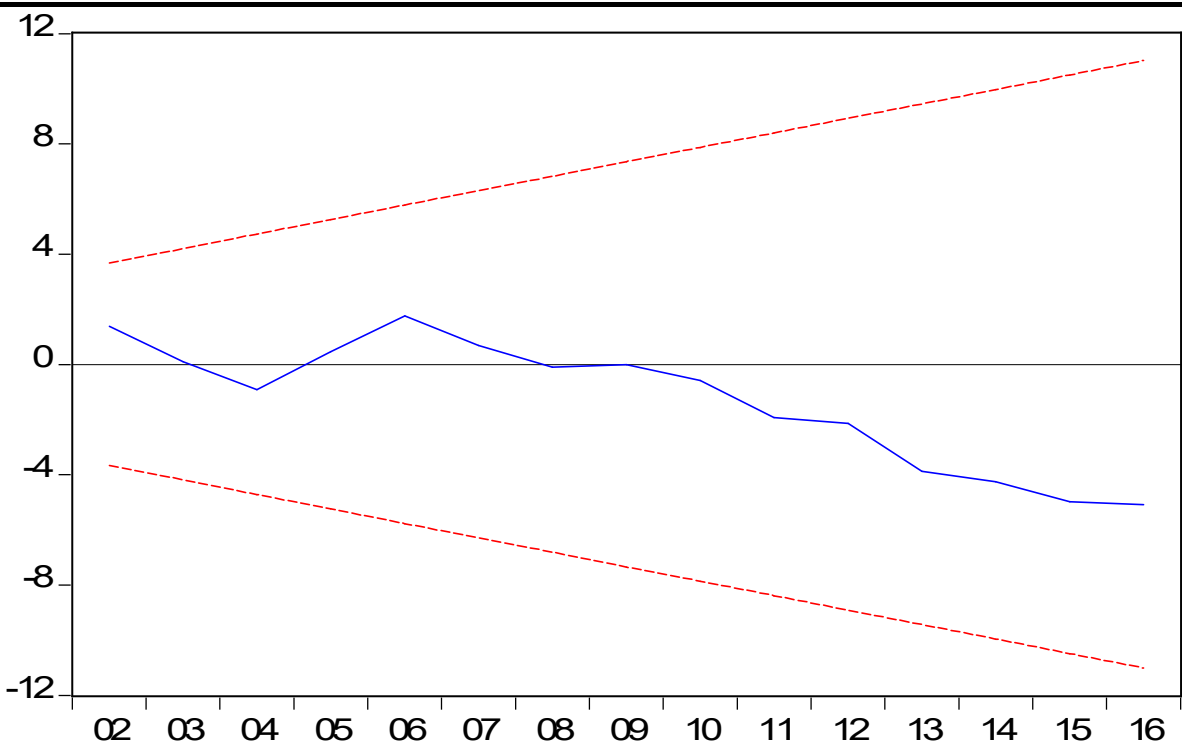

OSUM ----- 5\%Significance

Fig. 6: Plot of Cumulative Sum of Recursive Residuals (CUSUM)

The key output of the short-run dynamics is the computed coefficient of the error correction model (ECM). In line with a priori expectation, the ECM coefficient was negative and significant; an indication of the presence of cointegrating relationship among the variables. The $\mathrm{ECM}_{\mathrm{t}-1}$ value of -0.309 indicates that about 31 per cent of the disequilibria of the last year's shock to agricultural value added would adjust within the current year back to attain equilibrium level. Results of the relevant diagnostic tests are shown at the lower part of Table 5. The Pvalues indicated that the model do not have any evidence of serial correlation and heteroscedasticity. Furthermore, the model showed evidence of linearity while the CUSUM and CUSUMQ statistics indicated that all the coefficients in the error correction model were stable (see Fig. 6). 


\section{Conclusion and Policy Implications}

This study examined the impact of monetary policy on agricultural value added in Nigeria. With the use of the Autoregressive Distributed Lag (ARDL) approach through bounds testing and error correction model, we established that all the variables were cointegrated in the long run. Results from the ARDL approach indicate that in the long-run, money supply and maximum lending rate have significant effects on agriculture value added. Money supply had an expected positive sign with a coefficient of 1.29 and statistically significant at 1 per cent. This implies that monetary policy plays a significant role in improving agricultural sector performance in Nigeria. It also underscores the investment-stimulating role of money supply in the growth process. Agricultural investment requires adequate credit to purchase seed varieties, chemicals, labour, research and other services for optimal performance and this can be influenced through monetary policy actions.

The insignificant impact of REER suggests that the adopted exchange rate policies within the review period did not improve agricultural value added meaningfully. The low level of utilization of imported inputs and volume of agricultural exports connotes the weakness of the international competitiveness of the Nigerian economy. Overall, we can conclude that money supply has relatively stronger influence than other monetary policy variables on the Nigerian agricultural value added, in the long run.

In view of the foregoing conclusions, the paper recommends an expansionary but non-inflationary monetary policy to improve value addition to the agricultural sector of the Nigerian economy. In addition, the Nigerian exchange rate policy requires re-evaluation in order to appropriately support the competitiveness of the Nigerian agricultural economy at the international level.

\section{References}

Abiodun, E.O and Sheu, A.S. (2010). Agricultural response of prices and exchange rate in Nigeria: Application of cointegration and vector error correction model (VECM). Journal of Agricultural Science, 1 (2), 73-81.

Adeoye, B.W and Atanda, A.A (2012). Exchange rate volatility in Nigeria: Consistency, Persistency and severity analyses. CBN Journal of Applied Statistics, 2(2), 29 - 49.

Aroriode, J.R and Ogunbadejo, H.K. (2014). Impact of Macroeconomic Policy on Agricultural Growth in Nigeria. Journal of Agriculture and Veterinary Science, 7(2) [online] www.iosrjournals.com (Accessed 17 November, 2018).

Asfaha, T.A. \& Jooste, A. (2007). The effect of monetary changes on relative agricultural prices. Agrekon 46(4), 460-474 [Online] https://doi.org/10.1080/03031853. (Accessed on 05 December, 2018).

Babula, RA, Ruppel FJ and Bessler D.A. (1995). United States corn exports: The role of the exchange rate. Agricultural Economics, 13, 75-88.

Barnett, R.C., Bessler, D. A. and Thompson, R. L. (1981). Agricultural Prices in the 1970s and the Quantity Theory of Money'. Paper presented at the Annual Meeting of American Agricultural Economics Association. July 26-29, 1981. Clemson University. Clemson, South Carolina.

Benazić, M and Rami, J. (2016). Monetary Policy and Unemployment in Croatia. Economic Research-Ekonomska Istraživanja, 29 (1), 1038-1049.

Chambers, R. G. (1984). Agricultural and financial market interdependence in the short run. American Journal of Agricultural Economics, $66 \quad$ (1), [Online] https://academic.oup.com/ajae/articleabstract/66/1/12/95500?redirectedFrom=fulltext. (Accessed on 30 October, 2018).

Cioran, Z. and Cuza, A.I. (2014). Theories of Monetary Policy - From the Mercantilist Pragmatism to the Modern Monetary Theories. The USV Annals of Economics and Public Administration, 14 (1), 19-24.

Danmola, R.A. (2013). The impact of exchange rate volatility on the macro economic variables in Nigeria. European Scientific Journal, 9 (7), 152-165.

Devadoss, S. (1985). The impacts of monetary policies on US agriculture: Retrospective Theses and Dissertations'. 7838. [Online] https://lib.dr.iastate.edu/rtd/7838 (Accessed on 12 October, 2018).

Ehinomen, C. and Akorah, C.C. (2012). The impact of monetary policy on agricultural development in Nigeria (1970-2010). IOSR Journal of Humanities and Social Science, 5 (5), 13-25.

Fischer, S. (1993). The role of macroeconomic factors in growth. Journal of Monetary Economics, 32 (3), 485 511.

Gbosi, A.N. (2005). Monetary Policy and the Economy. (First Edition). Abigab Associates Ltd Confidence Estate, Uyo Nigeria.

Hayo, B. and Uhlenbrock, B. (1999). Industry Effects of Monetary Policy in Germany, Working Paper B99-14, Center for European Integration Studies (ZEI).

Ibrahim, M. H. (2005). Sectoral Effects of Monetary Policy: Evidence from Malaysia. Asian Economic Journal, $9,83-102$.

Jhingan M.L. (2010) Macroeconomic Theory. (12th Edition). Vrinda Publication Ltd, Delhi.

Kiptui, M. (2007). Does the exchange rate matter for Kenya's exports? A bound testing approach. Presentation at the African Economic Society Conference, July 4-6, Cape Town, South Africa. 
Lachaal, L. (1994). Subsidies, Endogenous Technical Efficiency and the Measurement of Production Growth. Journal of Agriculture and Applied Economics, 26 (1), 299-310.

Lucas, R.E. (1988). On the Mechanics of Economic Development. Journal of Monetary Economics, 22 (1), 3-42. Makinde, H.O. (2012). Monetary policy management implications on the movement of agricultural prices in Nigeria. African Journal of Business Management, 6 (46) 11401-11410.

Muroyiwa, B., Sitima I., Sibanda K., \& Mushonge, A. (2014). Monetary Policy Actions and Agricultural Sector Outcomes: Empirical Evidence from South Africa. Mediterranean Journal of Social Sciences, 5 (1), 613-620.

Oboh, V. U. and Adeleke, A. I. (2016). Accelerating Inclusive Agricultural Growth in Nigeria: An Examination of Strategic Issues, Challenges and Policy Options. International Journal of Development and Economic Sustainability, 4 (6), 1-25.

Odin, D. (1986). Money and agriculture: the dynamics of money-financial market-agricultural trade linkages. Agricultural Economics Research, 38 (3), 14-28.

Odin, D. and Fackler, P. (1989). Identifying monetary impacts on agricultural prices in VAR models. American Journal of Agricultural Economics, 71 (2), 495-502.

Olarinde, M.O. and Abdullahi, H. (2014). Macroeconomic Policy and Agricultural output in Nigeria: Implication for Food Security. American Journal of Economics, 4 (2), 99-113.

Oni, O., Nkonya, E., Pender, J., Phillips, D., \& Kato, E. (2009). Trends and Drivers of Agricultural Productivity in Nigeria. NSSP Report 1, Abuja, International Food Policy Research Institute (IFPRI).

Onwuka, I.O. (2017). Reversing Nigeria’s Food Import Dependency-Agricultural Transformation. Agricultural Development, 2 (1), [Online]

http://www.asianonlinejournals.com/index.php/AD/article/view/1006/html (Accessed on 12 November, 2018).

Onyilola, M.A. (2008). Exchange rate and disaggregated import prices in Nigeria. Journal of Economic and Monetary Integration, 9, 89-126.

Oriavwote, V.E. and Oyovwi, D.O. (2014). Does real effective exchange rate matters for agricultural output in Nigeria?: A cointegration approach. British Journal of Economics, Management and Trade, 4(1), 85-96.

Pesaran, M. H., Shin, Y. and Smith, R.J. (2001). Bounds Testing Approaches to the Analysis of Level Relationships. Journal of Applied Econometrics, 16, 289-326.

Romer, P. (1986). Increasing Returns and Long-Run Growth. Journal of Political Economy, 94 (5), $1002-1037$.

Schuh, G. E. (1974). The exchange rate and U.S agriculture. American Journal of Agricultural Economics, 56 (1), 1-13 [Online] http://hdl.handle.net/10.2307/1239342, (Accessed on 13 December, 2018).

Shei. S. (1978). The exchange rate and United States Agricultural Product Markets: A General Equilibrium Approach. Unpublished PhD. Dissertation, Purdue University, West Lafayette, Indiana

Sunday B, Vincent I, Glory E, Daniel E. (2012). Agricultural productivity and macroeconomic variable fluctuation in Nigeria. International Journal of Economics and Finance, 4 (8), 114-135.

Thapa, N.B. (2002). An Econometric Analysis of the Impact of Real Effective Exchange Rate on Economic Activities in Nepal. Economic Review: Occasional Paper, No. 14, April.

Todaro, M.P. and Stephen, C.S. (2004). Economic Development, Pearson Education (12th Ed.,). Singapore.

World Bank (2018). Agriculture, forestry, and fishing, value added (constant 2010 US\$). [Online] https://data.worldbank.org/indicator/NV.AGR.TOTL.KD. (Accessed on 18th December, 2018). 